\title{
Levels, trends and risk assessment of arsenic pollution in Yangzonghai Lake, Yunnan Province, China
}

\author{
WANG ZhenHua ${ }^{1}$, HE Bin ${ }^{1 *}$, PAN XueJun ${ }^{2}$, ZHANG KeGang ${ }^{1}$, WANG Chang ${ }^{1}$, SUN Jing ${ }^{1}$, \\ YUN ZhaoJun ${ }^{1} \&$ JIANG GuiBin ${ }^{1}$ \\ ${ }^{1}$ State Key Laboratory of Environmental Chemistry and Ecotoxicology; Research Center for Eco-Environmental Sciences, \\ Chinese Academy of Sciences, Beijing 100085, China \\ ${ }^{2}$ School of Environmental Science and Engineering, Kunming University of Science and Technology, Kunming 650093, China
}

Received March 11, 2010; accepted April 24, 2010

\begin{abstract}
The arsenic contamination accident in Yangzonghai Lake, Yunnan has been of wide concern. In order to investigate the arsenic distribution and concentration trends after the accident, samples including lake water, sediments, soil, aquatic organisms and crops were collected in November 2008, as well as in February, May and September 2009. The average arsenic concentrations (arithmetic average) in lake water in the four sampling events were 176.9, 147.3, 159.3, and 161.1 $\mu \mathrm{g} / \mathrm{L}$, while those in the sediments were $32.87,62.41,62.99$, and $46.96 \mu \mathrm{g} / \mathrm{g}$, respectively. The highest content of total arsenic in soil in the vicinity of Yangzonghai was $23.33 \mu \mathrm{g} / \mathrm{g}$, which was below the limits of the relevant national standard. The total arsenic levels in most aquatic plants were in the range of 100-200 $\mu \mathrm{g} / \mathrm{g}$, with Vallisneria natans (Lour.) Hara having the highest concentration of $\sim 300 \mu \mathrm{g} / \mathrm{g}$. The arsenic levels of fish and shrimps were in the range of 1.52-11.4 $\mu \mathrm{g} / \mathrm{g}$ (dry weight).
\end{abstract}

Yangzonghai Lake, arsenic pollution, level, trends, risk assessment

\section{Introduction}

Arsenic in the environment can transform from one species to another and transport from one matrix to another. Acute or chronic exposure to arsenic gives rise to harmful effects to human health and the ecological system, which can be sustained and difficult to eliminate in a short term [1]. Many countries and regions have the problem of arsenic pollution due to the discharge of industrial wastewater. The World Health Organization (WHO) revised the arsenic guideline value for drinking water quality to $10 \mu \mathrm{g} / \mathrm{L}$, which was also adopted in China in 2006.

Yangzonghai Lake is one of the largest plateau lakes in Yunnan province, China. It is the main water source for agriculture, fishery and drinking water for its surrounding

*Corresponding author (email: bhe@ $@$ rcees.ac.cn) areas. Because of the arsenic contamination accident in April 2008, the arsenic concentration in the water of Yangzonghai Lake increased to a level higher than grade III value of the Environment Quality Standards for Surface Water (GB3838-2002) in June 2008, and continued up to levels of 0.116 and $0.128 \mathrm{mg} / \mathrm{L}$ in July and September, respectively, which exceeded the grade V value of the Surface Water Environment Quality Standards (GB3838-2002). The arsenic concentration of lake water reached a maximum value of $0.134 \mathrm{mg} / \mathrm{L}$ on October 1 , and then decreased slowly. However, the average arsenic concentrations in lake water were lower than $0.006 \mathrm{mg} / \mathrm{L}$ before September 2007 $[2,3]$. Due to the arsenic pollution, the government of Yunnan province prohibited acquiring drinking water from Yangzonghai Lake, as well as swimming and fishing in it on September 12, 2008.

In this study, samples including lake water, sediments, aquatic organisms, as well as soil, crops and well water in 
Yangzonghai area were collected and analyzed. The objective of this study is to understand the trends and process of arsenic contamination in the plateau lake and provide support for pollution control and environmental protection.

\section{Materials and methods}

\subsection{Sampling site description}

Yangzonghai Lake $\left(24^{\circ} 51^{\prime}-24^{\circ} 58^{\prime} \mathrm{N}\right.$ and $\left.102^{\circ} 5^{\prime}-103^{\circ} 02^{\prime} \mathrm{E}\right)$ and its catchment area belong to Yiliang, Chenggong, and Chengjiang county, Yunnan. Yangzonghai Lake is a natural freshwater lake formed by the west extension fracture surface of Xiaojiang fault zone. The lake water is mainly accumulated from the surrounding Tangquan river and rain water. The average flux is about $2.1 \mathrm{~m}^{3} / \mathrm{s}$ in recent years. The outlet is the Tangdi canal in the south of the lake, which is a tributary of the Pearl River. The lake basin is composed of carbonate rocks, and the water is provided by Karst springs and underground rivers. Yangzonghai Lake served as the water source for the Yiliang fourth water plant before the pollution accident occurred. At the present, the main function of Yangzonghai is to provide water for industry, agriculture, landscapes and drinking.

\subsection{Samplings}

Figure 1 shows the sampling sites of the lake water, sediments, well water, soil and crops. Based on topographic features of Yangzonghai, the sampling sites were set as eight lake water and sediment sites (A, B, C, D, E, F, G, H), four soil sites $(1,2,3,4)$ and five well water and spring water sites (I, II, III, IV, V). The four sampling campaigns were carried out in December 2008, and February, May and September 2009. Table 1 shows the geographical coordinates of the sampling sites.

The vertical line was set at each sampling site in the lake for sampling lake water. There were several sampling sites along the vertical line in different depths. Two samples were collected at $0.5 \mathrm{~m}$ under the water surface and above the bottom of the lake, respectively. Along the sampling line, samples were collected every other $5 \mathrm{~m}$ from the water surface to the bottom of the lake. Polypropylene (PP) bottles $(100 \mathrm{~mL})$ were used to collect the water samples. Before sampling, all the sampling bottles were immersed in 50\% $(V / V)$ nitric acid solution for $12 \mathrm{~h}$. All the water samples were filtrated through $0.45 \mu \mathrm{m}$ filters and acidified with $1 \mathrm{~mL}$ concentrated nitric acid in field.

Sediment samples collected were sealed in polyethylene (PE) bags. Whole crops and plants were collected, classified and sealed in polyethylene bags and thereafter frozen at $-20{ }^{\circ} \mathrm{C}$.

\subsection{Water sample analysis}

The arsenic concentrations of water samples were analyzed by inductively coupled plasma mass spectrometry (ICP-MS) (7500ce, Agilent, USA) [4, 5]. The operating conditions for ICP-MS are shown in Table 2. The water samples were digested using a microwave-assisted method and acidified to $3 \%-5 \%(V / V)$ with concentrated nitric acid before determination.

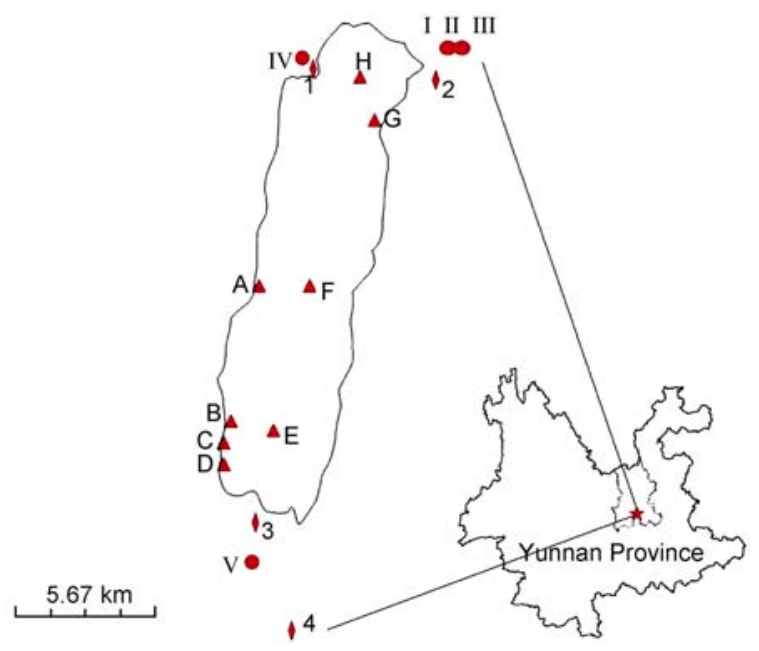

Figure 1 Map of sampling sites in Yangzonghai ( $\Delta$ lake water and sediments; $\bullet$ soil; $\bullet$ well water and spring water).

Table 1 Sampling sites of Yangzonghai

\begin{tabular}{|c|c|c|c|c|c|}
\hline Sampling site & $\begin{array}{c}\text { Geographical coordinates } \\
(N)\end{array}$ & $\begin{array}{c}\text { Geographical coordinates } \\
(E)\end{array}$ & Sampling site & $\begin{array}{c}\text { Geographical coordinates } \\
(N)\end{array}$ & $\begin{array}{c}\text { Geographical coordinates } \\
(E)\end{array}$ \\
\hline A & $24^{\circ} 54^{\prime} 27.60^{\prime \prime}$ & $102^{\circ} 59^{\prime} 19.98^{\prime \prime}$ & 1 & $24^{\circ} 57^{\prime} 18.96^{\prime \prime}$ & $103^{\circ} 0^{\prime} 15.60^{\prime \prime}$ \\
\hline B & $24^{\circ} 52^{\prime} 41.22^{\prime \prime}$ & $102^{\circ} 58^{\prime} 59.34^{\prime \prime}$ & 2 & $24^{\circ} 57^{\prime} 11.34^{\prime \prime}$ & $103^{\circ} 1^{\prime} 56.70^{\prime \prime}$ \\
\hline $\mathrm{C}$ & $24^{\circ} 52^{\prime} 17.64^{\prime \prime}$ & $102^{\circ} 58^{\prime} 53.16^{\prime \prime}$ & 3 & $24^{\circ} 51^{\prime} 10.36^{\prime \prime}$ & $102^{\circ} 59^{\prime} 21.33^{\prime \prime}$ \\
\hline $\mathrm{D}$ & $24^{\circ} 52^{\prime} 8.46^{\prime \prime}$ & $102^{\circ} 58^{\prime} 52.02^{\prime \prime}$ & 4 & $24^{\circ} 50^{\prime} 30.02^{\prime \prime}$ & $103^{\circ} 0^{\prime} 26.12^{\prime \prime}$ \\
\hline $\mathrm{E}$ & $24^{\circ} 52^{\prime} 34.86^{\prime \prime}$ & $102^{\circ} 59^{\prime} 29.94^{\prime \prime}$ & I & $24^{\circ} 57^{\prime} 45.66^{\prime \prime}$ & $103^{\circ} 2^{\prime} 9.30^{\prime \prime}$ \\
\hline $\mathrm{F}$ & $24^{\circ} 54^{\prime} 26.28^{\prime \prime}$ & $103^{\circ} 0^{\prime} 9.12^{\prime \prime}$ & II & $24^{\circ} 57^{\prime} 46.32^{\prime \prime}$ & $103^{\circ} 2^{\prime} 11.82^{\prime \prime}$ \\
\hline G & $24^{\circ} 56^{\prime} 34.86^{\prime \prime}$ & $103^{\circ} 1^{\prime} 7.14^{\prime \prime}$ & III & $24^{\circ} 57^{\prime} 46.37$ & $103^{\circ} 2^{\prime} 13.15^{\prime \prime}$ \\
\hline \multirow[t]{2}{*}{$\mathrm{H}$} & $24^{\circ} 57^{\prime} 10.62^{\prime \prime}$ & $103^{\circ} 0^{\prime} 54.72^{\prime \prime}$ & IV & $24^{\circ} 57^{\prime} 34.08^{\prime \prime}$ & $102^{\circ} 59^{\prime} 54.30^{\prime \prime}$ \\
\hline & & & V & $24^{\circ} 50^{\prime} 30.05^{\prime \prime}$ & $102^{\circ} 59^{\prime} 23.38^{\prime \prime}$ \\
\hline
\end{tabular}


Table 2 Optimum operating conditions for ICP-MS

\begin{tabular}{lc}
\multicolumn{1}{c}{ Parameters } & Optimum conditions \\
\hline RF Power & $1500 \mathrm{~W}$ \\
Sampling depth & $8.0 \mathrm{~mm}$ \\
Temperature of spray chamber & $-2{ }^{\circ} \mathrm{C}$ \\
Nebuliser & Babinton \\
Carrier gas (Ar) & $1.12 \mathrm{~L} / \mathrm{min}$ \\
Isotope & $75 \mathrm{As}$ \\
Flow rate of He & $4.5 \mathrm{~mL} / \mathrm{min}$ \\
\hline
\end{tabular}

\subsection{Solid sample analysis}

Sediment, soil and biological samples were lyophilized (Alpha 1-2 LD plus, Christ, Germany), ground, sieved (80 mesh), sealed in PE bags and frozen at $4{ }^{\circ} \mathrm{C}$ before analysis.

The procedure for sample preparation was as follows: (1) 0.1-0.2 g samples were weighed exactly into PTFE digestion tubes. (2) $3 \mathrm{~mL}$ concentrated nitric acid (65\%, Merck, USA) and $3 \mathrm{~mL}$ hydrogen peroxide (30\%, GR, Beijing Chemical Reagent, Beijing) were added. (3) The containers were put into a microwave-assisted digestion oven with the following program: the oven temperature was held at $120^{\circ} \mathrm{C}$ for $10 \mathrm{~min}$ after increasing in $10 \mathrm{~min}$ from room temperature; it was increased to $160{ }^{\circ} \mathrm{C}$ in $10 \mathrm{~min}$ and held for 10 $\mathrm{min}$; then the temperature was increased to $190{ }^{\circ} \mathrm{C}$ in 10 min and held for another $30 \mathrm{~min}$; finally, it was cooled to room temperature. After digestion, the samples were diluted to $50 \mathrm{~mL}$ by adding de-ionized water $(18.2 \mathrm{M} \Omega \mathrm{cm}$, Millipore, USA) and filtrated through $0.45 \mu \mathrm{m}$ membrane filter before determination with ICP-MS.

\subsection{Determination of $\mathrm{pH}$ and total organic carbon (TOC) of soil and sediment samples}

The $\mathrm{pH}$ values of soil and sediment samples were determined by the method NY/T1377-2007 [6] with water as the extractant.

The contents of total organic carbon (TOC) in soil and sediments were determined by TOC Analyzer (O.I Analyzer, College Station, TX, USA). Briefly, $0.1 \mathrm{~g}$ sample was weighted exactly and added into a quartz cuvette with quartz wool. Then 5\% phosphoric acid was dropped into the cuvette and allowed to react for 2-5 min. Then the cuvette was inserted into the instrument for TOC determination. The inorganic carbon was removed by roasting at $250{ }^{\circ} \mathrm{C}$ first, then the temperature was increased to $900{ }^{\circ} \mathrm{C}$ and held for $6 \mathrm{~min}$, and the non-dispersed infrared (NDIR) detection was conducted. The results are listed in Table 3.

\subsection{Quality assurance and quality control}

Standard reference materials (SRM) including Tibet soil (GBW08302), tea leaves (GBW (E) 080001), rice flour
Table 3 Contents of total organic carbon (TOC) in sediments

\begin{tabular}{ccccc}
\hline \multirow{2}{*}{$\begin{array}{c}\text { Sampling } \\
\text { site }\end{array}$} & \multicolumn{4}{c}{ TOC (wt \%) } \\
\cline { 2 - 5 } & first & $\begin{array}{c}\text { second } \\
\text { sampling }\end{array}$ & $\begin{array}{c}\text { third } \\
\text { sampling }\end{array}$ & $\begin{array}{c}\text { fourth } \\
\text { sampling }\end{array}$ \\
\hline A & 1.57 & 2.78 & 1.56 & 2.65 \\
B & 0.64 & 0.26 & 0.78 & 0.61 \\
C & 1.13 & 0.7 & 1.15 & 1.23 \\
D & 2.59 & 0.93 & 1.92 & 5.40 \\
E & 1.75 & 1.47 & 1.34 & 2.00 \\
F & 4.56 & 1.55 & 7.07 & 3.97 \\
G & 3.09 & 3.36 & 5.03 & 2.35 \\
H & 3.91 & 5.38 & 4.40 & 4.59 \\
\hline
\end{tabular}

(GBW08502) and Dorm-2 (Dogfish muscle, NRC, Canada) were used for validation of the analytical procedure. The results show that the concentrations agree with the certified values, which confirms the feasibility of the analytical protocols in determination of total arsenic in sediment, soil, plant and animal samples (Table 4). All analysis processes were performed in triplicates.

As for water samples, arsenate solution reference materials (GBW08667) were used to prepare the standard curves, and the concentrations were determined by using the internal calibration method.

\section{Results and discussion}

\subsection{The arsenic level and trends in lake water}

\subsubsection{The levels in lake water}

The lake water concentrations with varied depths in each sampling line were averaged and the results are shown in Figure 2. The arsenic concentrations in the four samplings were three times as high as the maximum allowable concentration (MAC) $(0.05 \mathrm{mg} / \mathrm{L})$ of grade III of the Surface Water Environmental Quality Standards (GB 3838-2002) and about 1.5-fold as that of grade V. It is therefore judged that the water quality could not meet the requirements for agricultural and general landscape usage.

The $\mathrm{pH}$ values of lake water were in the range of 8.70-9.10 and the lake water was mildly alkaline. Compared with the arsenic concentrations in other polluted water

Table 4 Analytical results of Standard Reference Materials (SRMs) (As: $\mu \mathrm{g} / \mathrm{g}$ )

\begin{tabular}{cccc}
\hline Name & $\begin{array}{c}\text { Certified value } \\
(\text { mean } \pm \text { SD })\end{array}$ & $\begin{array}{c}\text { Measured value } \\
(\text { mean } \pm \text { SD) }\end{array}$ & Recovery $(\%)$ \\
\hline GBW08302 & $3.8 \pm 0.4$ & $3.9 \pm 0.1$ & $103 \pm 3$ \\
GBW(E)08001 & $0.18 \pm 0.049$ & $0.19 \pm 0.002$ & $104 \pm 7$ \\
GBW08502 & $0.051 \pm 0.003$ & $0.052 \pm 0.003$ & $101 \pm 7$ \\
Dorm-2 & $18.0 \pm 1.1$ & $17.7 \pm 0.9$ & $98 \pm 2$ \\
\hline
\end{tabular}




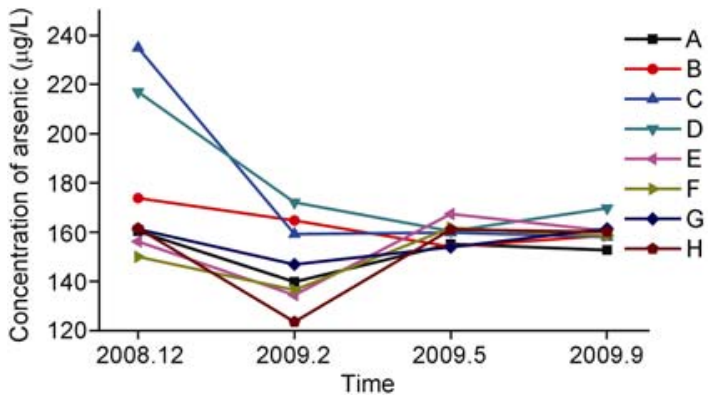

Figure 2 Average arsenic concentrations of lake water in Yangzonghai.

bodies in previous reports, the arsenic concentrations in the lake water of Yangzonghai were lower than those in Mono Lake, California, USA. (arsenic concentration: 10000-20000 $\mu \mathrm{g} / \mathrm{L}, \mathrm{pH} 9.5-10)$ [7], Union Lake in southern New Jersey $(2780 \mu \mathrm{g} / \mathrm{L})[8,9]$, water bodies in Ghana which was influenced by gold mining [10], and a series of subarctic lakes near Yellowknife, Northwest Territories, Canada (average level, $270 \mu \mathrm{g} / \mathrm{L}$, range of concentration, 64-530 $\mu \mathrm{g} / \mathrm{L}$ ) [11]. The arsenic concentrations in the lake water of Yangzonghai were higher than those in Manchar Lake in Pakistan (35-157 $\mu \mathrm{g} / \mathrm{L})$ [12], Moira Lake in Canada (35-100 $\mu \mathrm{g} / \mathrm{L})$ [13], etc., indicating that there was serious contamination in Yangzonghai.

According to the arithmetic mean arsenic concentration in the lake water and the capacity of Yangzonghai Lake during the four sampling occasions, the total arsenic contents in the lake were estimated roughly to be $105,82,89$, and 86 tons, respectively, indicating that total arsenic contents in the lake had been basically stable. The remarkable reduction of total arsenic contents from the first to the second sampling event might be attributed to adsorption of arsenic from the lake water into the sediment.

\subsubsection{Variation of arsenic concentrations in lake water}

Figure 2 shows the variation of arsenic concentrations in the lake water during the four sampling campaigns. During the first sampling event, the arsenic concentrations at sampling sites $\mathrm{B}, \mathrm{C}$ and $\mathrm{D}$ were higher than those at the other sites, and no significant differences in the arsenic concentrations were observed among the other sampling sites. The highest concentration $(234.8 \mu \mathrm{g} / \mathrm{L})$ occurred at site $\mathrm{C}$ because the site was close to the pollution source, while the lowest level $(150.1 \mu \mathrm{g} / \mathrm{L})$ was observed at site F. Meanwhile, an overall decreasing profile of arsenic concentration from the southern to the northern part was observed.

During the second sampling occasion, the arsenic concentrations at sites around $\mathrm{C}$ were still higher than those at other sites. However, the arsenic concentrations at B, C and $\mathrm{D}$ were lower than those during the first sampling. The arsenic concentrations at other sampling sites decreased in this sampling time. The concentration decline at sites $\mathrm{C}$ and $\mathrm{D}$ was significantly higher than that at the other sites in the lake. Considering the rapid increase of the total arsenic contents in the sediments at sites $\mathrm{C}$ and $\mathrm{D}$ during the second sampling time, the reduction of arsenic concentrations in the lake water was attributed to the adsorption of arsenic from lake water to the sediments. In this sampling event, the highest arsenic concentration $(172.7 \mu \mathrm{g} / \mathrm{L})$ occurred at site E, while the lowest $(123.8 \mu \mathrm{g} / \mathrm{L})$ was observed at site $\mathrm{H}$.

During the third sampling, the arsenic concentrations in the lake water at the different sites were all close to the average concentration in the lake and the arsenic concentrations were in the range of $167.5-154.0 \mu \mathrm{g} / \mathrm{L}$. The concentrations at the sites with high arsenic concentrations in the previous two samplings had decreased in this sampling time. However, the concentrations at sites with low arsenic concentrations had increased. It is therefore suggested the concentrations at different sites were gradually close to each other due to mixing of the lake water.

The arsenic concentrations during the fourth sampling were close to those in the third sampling, and little difference between the concentrations of each sampling sites was observed. The arsenic concentrations were in the range of $152.8-169.8 \mu \mathrm{g} / \mathrm{L}$. These results suggest that the arsenic concentrations in lake water approached equilibrium.

\subsubsection{Relationship between the arsenic concentrations and the depth of lake water}

Figure 3 shows the relationship between arsenic concentrations and depth of lake water. In the first sampling period, the arsenic concentrations in lake water at sites C and D increased rapidly with depth, whereas the concentrations and depth at the other sites were not much correlated. In the second sampling, the arsenic concentration at site $\mathrm{C}$ continued to increase with depth but the trend became less apparent. The reason may be that the spring water around site $\mathrm{C}$ brought arsenic pollutant into the lake water, and the arsenic pollutant in the spring water had been decreasing as time went on. During the third and fourth sampling periods, the arsenic concentrations did not vary with depth, indicating that the arsenic exchange between lake water and sediments approached equilibrium.

\subsubsection{The arsenic levels of groundwater and spring water}

To study the influence of the contamination accident on drinking water and other water of nearby villages, the arsenic concentrations of well water and spring water in Tangchi, Daying and Xinjie villages were investigated and the results are shown in Table 5. The arsenic concentrations in the five well water were in the range of $0.35-5.57 \mu \mathrm{g} / \mathrm{L}$ which did not exceed the maximum allowable concentration for drinking water quality of China (GB5749-2006) and guideline value of WHO for drinking water $(10 \mu \mathrm{g} / \mathrm{L})[14$, 15]. However, the concentration of spring water at sampling site I was higher than the limit and cannot be used for drinking. 

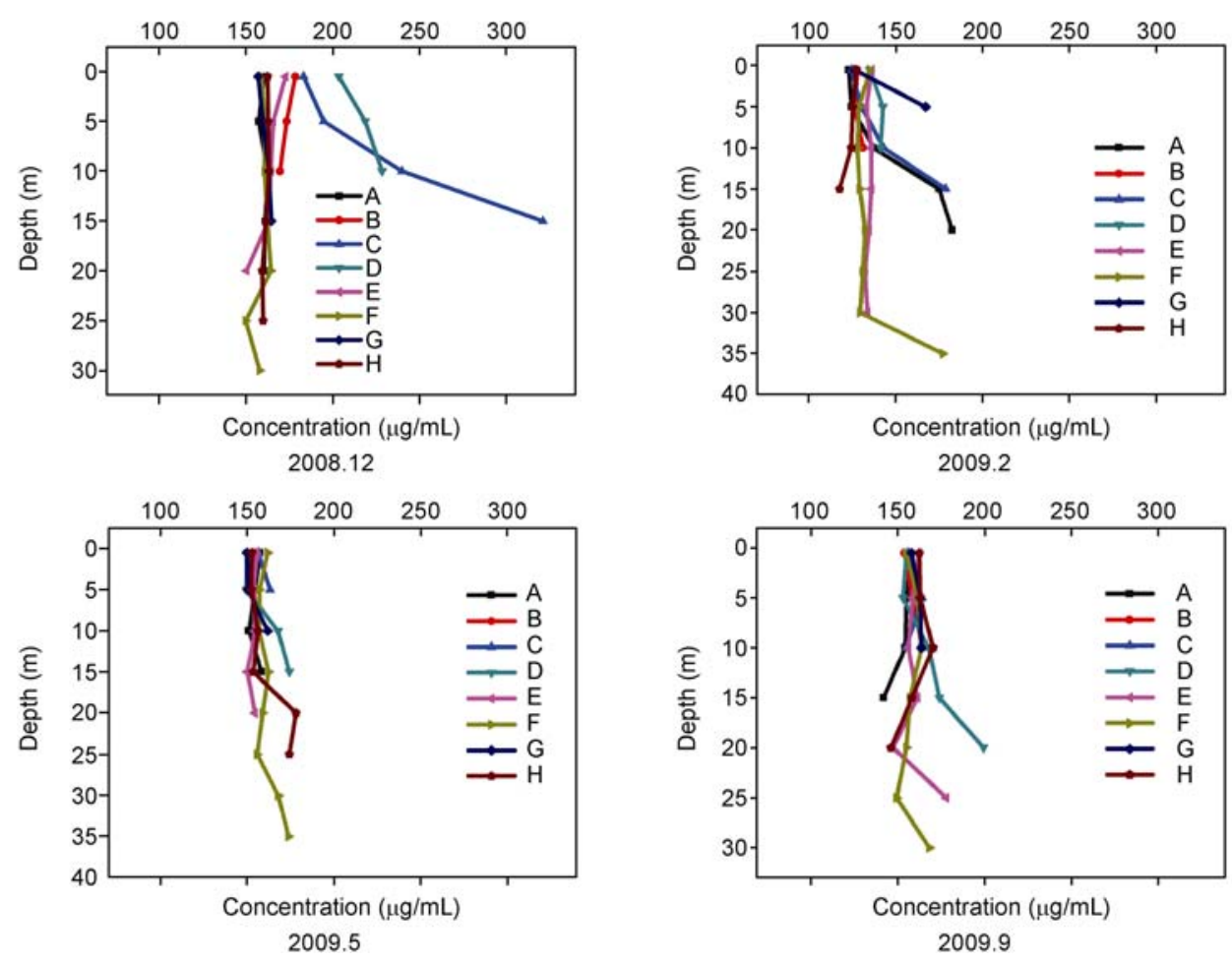

Figure 3 Relation between arsenic concentrations and depth of lake water in Yangzonghai.

Table 5 Arsenic concentrations in well water and spring water near Yangzonghai

\begin{tabular}{lc}
\hline Sampling site & Arsenic concentration $(\mu \mathrm{g} / \mathrm{L})$ \\
\hline Spring water of I & 10.50 \\
Well water of I & 0.35 \\
Well water of II & 5.57 \\
Well water of III & 0.98 \\
Well water of IV & 1.01 \\
Well water of V & 0.52 \\
\hline
\end{tabular}

\subsection{Arsenic levels in sediments and soil}

\subsubsection{The arsenic levels and trends in the sediments}

The arsenic exchange between lake water and sediments is a significant process of arsenic transportation. Table 6 shows the arsenic contents in the sediments at eight sampling sites and Figure 4 gives the trend of average arsenic contents in the sediments. Overall, the arsenic contents in the sediments in Yangzonghai were significantly lower than those in the contaminated water bodies in Ghana and Korea, and close to those sediments in Manchar Lake, Pakistan and West Bengal, India, and higher than those in other countries such as Argentina, France, Germany, Italy, Mexico, Japan, South Africa, Switzerland and United States (Table 7). These results illustrate that the levels in the sediments in Yangzonghai were high, and there was a trend of lower concentrations with distance from site $\mathrm{C}$.
Table 6 Arsenic contents in the sediment samples ( $\mu \mathrm{g} / \mathrm{g}$, dry weight)

\begin{tabular}{ccccc}
\hline $\begin{array}{c}\text { Sampling } \\
\text { site }\end{array}$ & $\begin{array}{c}\text { The first } \\
\text { sampling }\end{array}$ & $\begin{array}{c}\text { The second } \\
\text { sampling }\end{array}$ & $\begin{array}{c}\text { The third } \\
\text { sampling }\end{array}$ & $\begin{array}{c}\text { The fourth } \\
\text { sampling }\end{array}$ \\
\hline A & 24.63 & 52.13 & 55.08 & 40.00 \\
B & 48.11 & 109.9 & 100.2 & 95.30 \\
C & 75.82 & 164.7 & 140.6 & 133.1 \\
D & 21.11 & 52.68 & 44.64 & 23.21 \\
E & 13.47 & 18.00 & 19.03 & 16.93 \\
F & 24.31 & 20.12 & 44.55 & 17.56 \\
G & 44.01 & 55.93 & 81.84 & 37.28 \\
H & 11.47 & 25.80 & 17.98 & 12.33 \\
Mean & 32.87 & 62.41 & 62.99 & 46.96 \\
\hline
\end{tabular}

In December 2008, the arsenic concentrations in the sediments at sites $\mathrm{C}, \mathrm{B}$ and $\mathrm{G}$ were higher than those at the others, and the highest value of arsenic content was 75.82 $\mu \mathrm{g} / \mathrm{g}$. The lowest arsenic concentration occurred at site $\mathrm{H}$. However, arsenic contents in the sediments at most of the sampling sites in February 2009 were higher than those in December 2008. The contents in the sediments at sites A, B, $\mathrm{C}, \mathrm{D}$ and $\mathrm{H}$ during the second sampling period were about twice as high as those in the first sampling event. Considering the rapid decrease of arsenic concentrations in the lake water during the second sampling time, the rapid increase of arsenic contents in the sediments may be the result of transportation of arsenic from the lake water into the sediment. The local vegetation around the lake grew vigorously throughout the year, and there was a large amount of organic 
Table 7 Arsenic contents in the sediments and soil in other countries $(\mu \mathrm{g} / \mathrm{g}$, dry weight)

\begin{tabular}{lcc}
\hline \multicolumn{1}{c}{ Country } & Range value & Mean \\
\hline Ghana [10] & $942-10200$ & - \\
Pakistan & $11.3-55.8$ & 26.8 \\
Korea & $119-2400$ & $1110 \pm 474$ \\
India & $10-196$ & - \\
Bangladesh & $9.0-28$ & 22.1 \\
Argentina & $0.8-22$ & 5 \\
China & $0.01-626$ & 11.2 \\
France & $0.1-5$ & 2 \\
Germany & $2.5-4.6$ & 3.5 \\
Italy & $1.8-60$ & 20 \\
Japan & $0.4-70$ & 11 \\
Mexico & $2-40$ & 14 \\
South Africa & $3.2-3.7$ & - \\
Switzerland & $2-2.4$ & 2.2 \\
United States & $1.6-72$ & 7.5 \\
\hline
\end{tabular}

matter in the sediments in Yangzonghai and consequently the contents of TOC in the sediments were relatively high. High contents of organic matter or TOC in the sediment may play a significant role in adsorbing arsenic from lake water into sediments $[16,17]$. High concentrations of manganese in the sediments $(500-1200 \mu \mathrm{g} / \mathrm{g}$ ) could also contribute to the adsorption of arsenic on the sediments as it was reported that the adsorption of arsenic could be strengthened in the presence of manganese oxides, amorphous iron oxides and clay minerals $[17,18]$.

The arsenic contents in the sediments around site $\mathrm{C}$ decreased to $24.13 \mu \mathrm{g} / \mathrm{g}$ in May 2009, while the contents in other sites increased. These results show that the arsenic in the sediments around site $\mathrm{C}$ began to be slowly released, but arsenic in lake water at other sites was still adsorbed onto the sediments.

Compared with the third sampling period, the arsenic contents in the sediments at all the sites decreased in September 2009. The arsenic contents at sites B, C and D were 95.30, 133.1 and $23.21 \mu \mathrm{g} / \mathrm{g}$, respectively. The arsenic contents at sites $\mathrm{B}$ and $\mathrm{C}$ were still the highest among the eight sampling sites. These show that the arsenic in the sediments at all sampling sites had diffused into the lake water slowly. The reason may be that (1) with manganese concentration above $5 \mu \mathrm{g} / \mathrm{L}$ in the lake water and weakly alkaline lake water, the manganese oxyhydroxides and iron oxyhydroxides could be formed easily, which could strengthen the dissolution of arsenic in the sediments [17]. (2) With the higher biological activity in spring and summer than the other seasons, the microbial reduction of arsenic could promote the dissolution of arsenic in the sediments [19-21]. As the lake water and sediments were mildly alkaline and

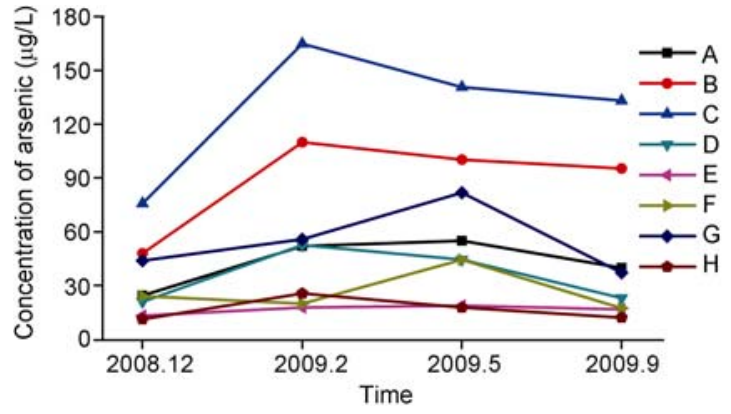

Figure 4 Average arsenic contents in the sediments in Yangzonghai.

arsenic was stable under neutral conditions, the arsenic in the sediments could be released slowly [18].

According to the above discussion, we concluded that the arsenic concentrations in the lake water first decreased rapidly, then increased slowly, and finally leveled off, while the contents in the sediments increased rapidly in December 2008, and then decreased slowly from February 2009. The reason may be that the arsenic in lake water was first adsorbed into sediments and then the arsenic in the sediments slowly diffused into the lake water.

\subsubsection{Arsenic levels in the nearby soil}

Arsenic may pollute the nearby soils and farmland by irrigation or diffusion. In order to assess the impact of the pollution accident on the nearby soil and farmland, arsenic contents in soil samples collected around Yangzonghai area in May and September 2009 were determined, and the results are shown in Table 8.

The arsenic concentration at sampling site 4, which was located on the hill in the southern part of Yangzonghai, was not influenced by the arsenic pollution accident, and this site can be considered as the background site for the local area. Soil at sites 2 and 3 can be used to study the impact of arsenic pollution because they had been irrigated with the

Table 8 Arsenic contents in the soil samples near Yangzonghai $(\mu \mathrm{g} / \mathrm{g}$, dry weight)

\begin{tabular}{cccc}
\hline Sampling time & Sampling site & Value $(\mu \mathrm{g} / \mathrm{g})$ & $\mathrm{pH}$ \\
\hline \multirow{2}{*}{ May, 2009 } & $2-1$ & 8.72 & 7.73 \\
& $2-2$ & 29.69 & 7.06 \\
& 3 & 21.66 & 7.23 \\
& 1 & 24.84 & 8.40 \\
September, 2009 & $2-1$ & 6.50 & 7.30 \\
& $2-2$ & 23.33 & 7.96 \\
& 3 & 21.24 & 7.90 \\
& $4-1$ & 22.49 & 7.65 \\
& $4-2$ & 10.89 & 6.95 \\
\hline
\end{tabular}


lake water of Yangzonghai. As the arsenic contents in the soil at sites 2 and 3 were lower than the grade III limit $(30 \mu \mathrm{g} / \mathrm{g}$ ) of Environment Quality Standard for Soil (GB 15618-1995), we concluded that these two areas can still be used as farmland. The arsenic contents at all sites had decreased from May. The reason may be arsenic uptake by crops or washout by rainwater.

\subsection{The arsenic levels in aquatic organisms and crops}

The arsenic levels in aquatic plants are shown in Table 8. The highest arsenic concentration in all the aquatic plants studied was in Vallisneria natans (Lour.) Hara and the concentrations in the leaves and roots were 324 and $855 \mu \mathrm{g} / \mathrm{g}$, respectively. This was followed by Hydrilla verticillata, Potamogeton malaianus Mig and Potamogeton lucens. It was reported that arsenic concentrations in the roots of $\mathrm{Na}$ jas marina, Potamogeton lucens, Nuphar luteum (Linn.) and Potamogeton malaianus Mig were 15.9, 12.7, 8 and $7 \mu \mathrm{g} / \mathrm{g}$ (dry weight), respectively, and the concentrations in the other parts were lower than $1 \mu \mathrm{g} / \mathrm{g}$ (dry weight) [22], which were lower than those in the corresponding plants in Yangzonghai. The arsenic level in the root of Eichhornia crassipes (Mart.) Solms collected in Kuala Lumpur, Selangor, Malaysia was $143.8 \mu \mathrm{g} / \mathrm{g}$ (dry weight) [23], which was higher than that in the Eichhornia crassipes (Mart.) Solms collected in Yangzonghai. The concentration in the leaves was $19.2 \mu \mathrm{g} / \mathrm{g}$ (dry weight) [23], which was lower than that in the Eichhornia crassipes (Mart.) Solms collected in Yangzonghai. The above results illustrate that the aquatic plants collected in Yangzonghai had high levels of arsenic. Furthermore, the aquatic plants collected from Yangzonghai Lake had higher arsenic enrichment ability than the same type of plants in the other area reported previously.

\subsubsection{The arsenic levels in aquatic animals}

The arsenic levels in fish samples in Yangzonghai were in the range of $1.52-11.42 \mu \mathrm{g} / \mathrm{g}$ (dry weight) (Table 9). It was reported that the arsenic levels in fish were $0.05-1.4 \mu \mathrm{g} / \mathrm{g}$ (wet weight) [24] in Lake Michigan, 6.1-11.8 $\mu \mathrm{g} / \mathrm{g}$ (dry weight) [25] and 2.12-15.2 $\mu \mathrm{g} / \mathrm{g}$ (dry weight) [26] in Lake Manchar, Pakistan, 0.038-0.309 $\mu \mathrm{g} / \mathrm{g}$ (dry weight) [27] in River Neretva, Croatia, 0.396-12.58 $\mu \mathrm{g} / \mathrm{g}$ [28] in southeastern Spain and 0.57-1.15 $\mu \mathrm{g} / \mathrm{g}$ [29] in five different fish species in Back Bay, Great Slave Lake, near the city of Yellowknife, NT, Canada. It was also reported that the arsenic contents in freshwater fish were respectively 1.6-3.8 and 7.9-22.2 $\mu \mathrm{g} / \mathrm{g}$ in non-contaminated and contaminated areas of Thailand [30], 0.097-1.32 $\mu \mathrm{g} / \mathrm{g}$ in Bangladesh [31], and $0.27-10.3 \mu \mathrm{g} / \mathrm{g}$ [32] in Brazil. Compared with the above results, the arsenic concentrations in fish and shrimps collected in Yangzonghai after the pollution accident were at a relatively high level.

\subsubsection{The levels in crops near Yangzonghai}

The arsenic contents in the crop samples are shown in Table 10. The contents in the edible parts of rice, corn, cauliflower and small cole were $0.15,0.09-0.14,0.15$ and $0.35 \mu \mathrm{g} / \mathrm{g}$ (dry weight), respectively, which were lower than limits of the relevant non-polluted food standards [33-36]. The order of arsenic contents in the different crops was small cole $>$ rice $>$ cauliflower $>$ corn. The arsenic contents of edible parts of rice, corn and cauliflower were lower than those of non-edible parts such as leaves, stems and roots. This was consistent with the results from previously reported studies [37].

\section{Conclusions}

By tracking the arsenic levels in Yangzonghai for almost one year after the contamination incident, the levels and trends of arsenic pollution were investigated, and the impact on the surrounding environment was studied. The results of this study indicate that (1) the arsenic levels in lake water, sediments, aquatic plants, shrimps and fish were compara-

Table 9 Arsenic contents in aquatic organisms ( $\mu \mathrm{g} / \mathrm{g}$, dry weight)

\begin{tabular}{|c|c|c|c|}
\hline Samples & Value ( $\mu \mathrm{g} / \mathrm{g}$, dry weight) & Samples & Value ( $\mu \mathrm{g} / \mathrm{g}$, dry weight) \\
\hline Hydrilla verticillata & $213 \pm 49$ & Leaf of Vallisneria natans (Lour.) Hara & $324 \pm 45$ \\
\hline Myriophyllum verticillatum & $169 \pm 64$ & Root of Vallisneria natans (Lour.) Hara & $855 \pm 99$ \\
\hline Chlorophyta & $103 \pm 39$ & Chara braunii & $142 \pm 29$ \\
\hline Ceratophyllum demersum $\mathrm{L}$. & $163 \pm 15$ & Leaf of Eichhornia crassipes (Mart.) Solms & $21.9 \pm 2.9$ \\
\hline Nitellopsis obtusa & $159 \pm 27$ & Root of Eichhornia crassipes (Mart.) Solms & $75.5 \pm 14.8$ \\
\hline Potamogeton pectinatus $\mathrm{L}$. & $110 \pm 81$ & Shrimp & $11.1 \pm 1.0$ \\
\hline Potarnogeton malaianus Mig & $191 \pm 84$ & Carassius auratus & $11.4 \pm 5.6$ \\
\hline Potamogeton lucens & $134 \pm 20$ & Tilapia & $5.46 \pm 2.03$ \\
\hline \multirow[t]{2}{*}{ Potamogeton maackianus } & $143 \pm 45$ & Swordfish & $4.85 \pm 0.69$ \\
\hline & & Monopterus albus & $1.52 \pm 0.16$ \\
\hline
\end{tabular}


Table 10 Arsenic contents in the crops near Yangzonghai ( $\mu \mathrm{g} / \mathrm{g}$, dry weight)

\begin{tabular}{lclc}
\hline \multicolumn{1}{c}{ Samples } & Value $(\mu \mathrm{g} / \mathrm{g}$, dry weight $)$ & \multicolumn{1}{c}{ Samples } & Value $(\mu \mathrm{g} / \mathrm{g}, \mathrm{dry}$ weight $)$ \\
\hline Rice kernels at site 3 & $0.15 \pm 0.09$ & Corn kernels at site 2 & $1.06 \pm 0.03$ \\
Rice husk at site 3 & $0.50 \pm 0.01$ & Corncob at site 2 & $1.22 \pm 0.06$ \\
Rice leaf at site 3 & $7.60 \pm 0.36$ & Corn leaf at site 2 & $0.14 \pm 0.02$ \\
Rice root at site 3 & $23.8 \pm 1.3$ & Corn stem at site 2 & $0.23 \pm 0.05$ \\
Corn kernels at site 3 & $0.090 \pm 0.003$ & Corn root at site 2 & $0.62 \pm 0.01$ \\
Corncob at site 3 & $0.58 \pm 0.02$ & Flower of cauliflower at site 3 & $0.26 \pm 0.05$ \\
Corn root at site 3 & $8.76 \pm 0.37$ & Leaf of cauliflower at site 3 & $0.15 \pm 0.01$ \\
Small cole at site 3 & $0.12 \pm 0.01$ & Root of cauliflower at site 3 & $0.23 \pm 0.03$ \\
\hline
\end{tabular}

tively high. There was a potential threat to the surrounding environment and health of local residents. (2) The temporal trend of arsenic concentration variation in the lake water in Yangzonghai first showed an increase and then a decrease, and finally leveled off. The arsenic contents in the sediments increased rapidly and then decreased slowly. The arsenic exchange between lake water and sediments still occurs. (3) The slow reduction of arsenic content in the lake water of Yangzonghai in the past year indicates that the self-purification ability of the water body of Yangzonghai was weak, thus human intervention was required to restore the water quality as soon as possible. (4) The arsenic level in drinking water, soil and crops in the nearby area of Yangzonghai met the relevant national standards, but the arsenic content of soil was close to the critical value. The arsenic levels in fish and shrimps were comparatively high and unfit for human consumption. The measure of lake closure made the arsenic contamination under temporary control after the accident. However, ill management may result in broader pollution and harmful effects on human beings. Therefore, the fundamental way to solve this pollution problem is to reduce the levels of arsenic in the lake.

This work was jointly supported by the National Basic Research Program of China (2009CB421605), the National Natural Science Foundation of China (20677069) and Key Project in Foreign Cooperation of Chinese Academy of Sciences (GJHZ 0907).

1 Mandal BK, Suzuki KT. Arsenic round the world: A review. Talanta, 2002, 58(1): 201-235

2 Liu Y. Joking remarks of Yangzonghai: Review of contamination accident. Water \& Wastewater Information, 2009, (2): 39-41

3 Environmental Protection Agency of Yunnan. Highland Lake Water Quality Report. 2008-2010. http://www.ynepb.gov.cn/color/default.aspx

4 U.S. Environmental Protection Agency. Determination of trace elements in waters and wastes by inductively coupled plasma-mass spectrometry (EPA 200.8). 1994

5 Wen XY, Song JW, Tan YL, Zhang FL, Deng JF. The research on the measurement for $\mathrm{As}, \mathrm{Sb}, \mathrm{Se}$ in drinking water directly with ICP-MS. Environmental Monitoring in China, 2005, 21(3): 22-25

6 China Ministry of Agricutrue. NY/T 1377-2007. Determination of $\mathrm{pH}$ in Soils. Beijing: 2007

7 Maest AS, Pasilis SP, Miller LG, Nordstrom DK. Redox geochemistry of arsenic and iron in Mono Lake, California, USA. A a
Balkema: Rotterdam, 1992, 507-511

8 Faust SD, Winka A, Belton T, Tucker R. Assessment of the chemical and biological significance of arsenical compounds in a heavlily contaminated watershed. 2. Analysis and distribution of several arsenical species. J Environ Sci Health Part A-Environ Sci Eng Toxic Hazard Subst Control, 1983, 18(3): 389-411

9 Faust SD, Winka AJ, Belton T. An assessment of chemical and biological significance of arsenical species in the Maurice River Drainage-Basin (NJ) 2. partitioning of arsenic into bottom sediments. $J$ Environ Sci Health Part A-Environ Sci Eng Toxic Hazard Subst Control, 1987, 22(3): 239-262

10 Serfor-Armah Y, Nyarko BJB, Adotey DK, Dampare SB, Adomako D. Levels of arsenic and antimony in water and sediment from Prestea, a gold mining town in Ghana and its environs. Water Air Soil Pollut, 2006, 175(1-4): 181-192

11 Bright DA, Dodd M, Reimer KJ. Arsenic in subArctic lakes influenced by gold mine effluent: The occurrence of organoarsenicals and 'hidden' arsenic. Sci Total Environ, 1996, 180(2): 165-182

12 Arain MB, Kazi TG, Baig JA, Jamali MK, Afridi HI, Shah AQ, Jalbani N, Sarfraz RA. Determination of arsenic levels in lake water, sediment, and foodstuff from selected area of Sindh, Pakistan: Estimation of daily dietary intake. Food and Chemical Toxicology, 2009, 47(1): 242-248

13 Azcue JM, Nriagu JO. Impact of abandoned mine tailings on the arsenic concentrations in Moira lake, Ontario. J Geochem Explor, 1995, 52(1-2): 81-89

14 China Ministry of Health, Standardization Administration of the People's Republic of China. Standards for Drinking Water Quality (GB 5749-2006). Beijing, 2006

15 World Health Organization. Guidelines for Drinking-Water Quality, third edition. World Health Organization, Geneva 2004, 306

16 Paikaray S, Banerjee S, Mukherji S. Sorption of arsenic onto Vindhyan shales: Role of pyrite and organic carbon. Curr Sci, 2005, 88(10): 1580-1585

17 Reza A, Jean JS, Yang HJ, Lee MK, Woodall B, Liu CC, Lee JF, Luo SD. Occurrence of arsenic in core sediments and groundwater in the Chapai-Nawabganj District, northwestern Bangladesh. Water Res, 2010, 44(6): 2021-2037

18 Shaw D. Mobility of arsenic in saturated, laboratory test sediments under varying pH conditions. Eng Geol, 2006, 85(1-2): 158-164

19 McArthur JM, Ravenscroft P, Safiulla S, Thirlwall MF. Arsenic in groundwater: Testing pollution mechanisms for sedimentary aquifers in Bangladesh. Water Resour Res, 2001, 37(1): 109-117

20 Mukherjee $\mathrm{AB}$, Bhattacharya $\mathrm{P}$. Arsenic in groundwater in the Bengal Delta Plain: Slow poisoning in Bangladesh. Environ Rev, 2001, 9(3): 189-220

21 Bhattacharya P, Jacks G, Ahmed KM, Routh J, Khan AA. Arsenic in groundwater of the Bengal Delta Plain aquifers in Bangladesh. Bull Environ Contam Toxicol, 2002, 69(4): 538-545

22 Mazej Z, Germ M. Trace element accumulation and distribution in four aquatic macrophytes. Chemosphere, 2009, 74(5): 642-647 
23 Lee CK, Low KS, Hew NS. Accumulation of arsenic by aquatic plants. Sci Total Environ, 1991, 103(2-3): 215-227

24 Nicholson LW, Rengan K. Determination of arsenic in some lake-michigan fish using neutron-activation analysis. $J$ Radioanal Chem, 1979, 54(1-2): 355-360

25 Shah AQ, Kazi TG, Baig JA, Arain MB, Afridi HI, Kandhro GA, Wadhwa SK, Kolachi NF. Determination of inorganic arsenic species $\left(\mathrm{As}^{3+}\right.$ and $\left.\mathrm{As}^{5+}\right)$ in muscle tissues of fish species by electrothermal atomic absorption spectrometry (ETAAS). Food Chem, 2010, 119(2): $840-844$

26 Shah AQ, Kazi TG, Arain MB, Jamali MK, Afridi HL, Jalbani N, Baig JA, Kandhro GA. Accumulation of arsenic in different fresh water fish species-potential contribution to high arsenic intakes. Food Chem, 2009, 112(2): 520-524

27 Has-Schon E, Bogut I, Strelec I. Heavy metal profile in five fish species included in human diet, domiciled in the end flow of River Neretva (Croatia). Arch Environ Contam Toxicol, 2006, 50(4): 545-551

28 Delgado-Andrade C, Navarro M, Lopez H, Lopez MC. Determination of total arsenic levels by hydride generation atomic absorption spectrometry in foods from south-east Spain: Estimation of daily dietary intake. Food Addit Contam, 2003, 20(10): 923-932

29 de Rosemond S, Xie QL, Liber K. Arsenic concentration and speciation in five freshwater fish species from Back Bay near
Yellowknife, NT, Canada. Environ Monit Assess, 2008, 147(1-3): 199-210

30 Jankong P, Chalhoub C, Kienzl N, Goessler W, Francesconi KA, Visoottiviseth P. Arsenic accumulation and speciation in freshwater fish living in arsenic-contaminated waters. Environ Chem, 2007, 4(1): 11-17

31 Al Rmalli SW, Haris PI, Harrington CF, Ayub M. A survey of arsenic in foodstuffs on sale in the United Kingdom and imported from Bangladesh. Sci Total Environ, 2005, 337(1-3): 23-30

32 Moretto AL, Cadore S. Determination of arsenic in food samples by hydride generation-atomic absorption spectrometry. Microchim. Acta, 2004, 146(3-4): 239-244

33 National programme on safety food. NY5115-2008 Safety milled rice criteria of PR China. Beijin: China Ministry of Health. 2008

34 National programme on safety food. NY5302-2005 Safety crop criteria of PR China. Beijin: China Ministry of Health. 2005

35 National programme on safety food. NY5008-2008 Safety Brassica criteria of PR China. Beijing: China Ministry of Health. 2008

36 National programme on safety food. NY5003-2008 Safety cabbage criteria of PR China. China Ministry of Health. 2008

37 Jung MC, Thornton I, Chon HT. Arsenic, Sb and Bi contamination of soils, plants, waters and sediments in the vicinity of the Dalsung Cu-W mine in Korea. Sci Total Environ, 2002, 295(1-3): 81-89 